\title{
HEDONISME KRISTEN JOHN PIPER SEBAGAI SEBUAH KONTEKSTUALISASI DI DALAM IMAN KRISTEN
}

\author{
Rusli \\ Sekolah Tinggi Teologi Reformed Injili Internasional, Jakarta
}

\begin{abstract}
Every era always challenges Christian faith, but the mission is still the same, how to conquer the world in God's truth. After struggling with modern era, Christian faith is facing other problems in the postmodern era. John Piper's point of view which is called Christian hedonism is born in the midst of self seeking pleasure challenge in postmodern era. Although this view actually becomes a blessing for Christianity yet it is also raising critics and contradiction. The concern and objection about Piper's view in Christian hedonism was whether or not Piper make a compromise of the Word of God, the Truth, with the sinful world. We will learn that Piper was doing contextualization than to compromise the Christian faith. Piper's work always stands firm in God's Truth with the Bible's relevance and the faithfulness of the Gospel.
\end{abstract}

KEYWORDS: Contextualization, Christian hedonism, pleasure, enjoy, affection, joy in Christ, relevance and faithfulness.

ABSTRACT: Iman Kristen selalu menghadapi tantangan di dalam setiap zaman, tetapi tugas penting yang harus dikerjakan tidak pernah berubah, 
yaitu bagaimana menaklukkan zaman di dalam kebenaran Tuhan. Setelah bergumul dalam zaman modern, iman Kristen menghadapi tantangan lainnya di dalam zaman postmodern. Pandangan John Piper yang dikenal dengan hedonisme Kristen lahir di tengah-tengah tantangan "self-seeking pleasure" dalam zaman postmodern. Meskipun pandangan ini telah menjadi berkat besar di dalam kekristenan, namun kritik dan kontradiksi juga tidak terhindarkan ditujukan kepada Piper. Perhatian dan keberatan yang muncul berkenaan dengan pertanyaan apakah Piper mengkompromikan kebenaran Firman Tuhan dengan situasi dunia berdosa. Pembahasan akan menunjukkan bahwa pandangan Piper bukan suatu kompromi, melainkan kontekstualisasi dan apa yang Piper kerjakan senantiasa berpegang pada kebenaran Kristen dengan relevansi dan kesetiaan kepada berita Injil.

KATA KUNCI: Kontekstualisasi, hedonisme Kristen, kenikmatan, afeksi, sukacita di dalam Kristus, relevansi dan kesetiaan.

\section{Signifikansi Hedonisme Kristen dalam Era Postmodern}

Hedonisme Kristen menjadi sebuah istilah yang kontroversial, apalagi ketika istilah ini dipakai untuk menggambarkan orang-orang Kristen sejati. Istilah hedonisme memiliki nuansa duniawi dipengaruhi oleh filsuf Yunani, Epicurus, yang menjadikan kesenangan sebagai the highest good/ the sole good. ${ }^{1}$ Menurut J. Philip Wogaman konsep ini pada akhirnya menjadi sebuah

1 Peter Adam Angeles, The Harpercollins Dictionary of Philosophy, 2nd ed. (New York: Harper Collins, 1992), 123. 
pandangan tentang pengejaran kepuasan yang berpusat pada diri sendiri. ${ }^{2}$ Di lain pihak, kekristenan meletakkan dasar pengajarannya pada pengenalan akan Allah yang berpusat pada pribadi Allah sebagai tujuan utamanya. Akibatnya, terjadi pro dan kontra di kalangan kekristenan atas pemilihan istilah yang dipakai oleh John Piper ini, bahkan teolog yang tidak setuju dengan pandangan ini melihat bahwa Piper telah memberikan toleransi terhadap keinginan zaman secara negatif dan dianggap sebagai kompromiuntuk menyenangkan zaman. ${ }^{3}$

Perdebatan-perdebatan yang muncul menjadi contoh adanya kesenjangan (gap) pemahaman tentang konsep hedonisme Kristen meskipun di beberapa tempat konsep ini telah menjadi berkat bagi banyak orang di dalam pertumbuhan iman mereka untuk tetap teguh dan berakar dalam pengenalan Allah, khususnya di era postmodern dimana relativisme membuat manusia tidak lagi mempercayai kebenaran obyektif. Idiom "up to $u s^{\prime \prime 4}$ yang mengandung makna bahwa kebenaran tertinggi manusia adalah apa yang saya suka mengakibatkan kekacauan dalam hidup manusia karena standar kesukaan setiap orang itu relatif. Pola pikir ini juga menyentuh hal rohani dimana manusia telah menggeser Allah sejati dan menciptakan allahnya sendiri. Tantangan mulai timbul, bagaimana pengajaran sejati untuk mengenal Kristus bisa tetap diberitakan dan mandat agung yang diperintahkan Tuhan tetap dijalankan. Mengikut arus bukanlah solusi yang

\footnotetext{
2 J. Philip Wogaman, Christian Ethics (London: SPCK, 1994), 21.

3 Richard J. Mouw, The God Who Commands (Notre Dame: University of Notre Dame Press, 1990), 30 .

4 R. Scott Smith, Truth and the New Kind of Christian: The Emerging Effects of Postmodernism in the Church (Wheaton: Crossway, 2005), 18.
} 
benar, tetapi menentang arus secara ekstrim bukanlah suatu keputusan bijak, sehingga bagaimana melihat zaman adalahtugas penting yang harus dicermati untuk melaksanakan kehendak Allah di zaman dimana kita hidup.

Untuk menjawab tantangan zaman, memang bijak belajar dari sejarah tetapi dalam penerapannya tidak bisa disama-ratakan. Penerapan metodemetode yang telah dipakai di masa lalu tidak bisa diterapkan langsung 'copy-paste' untuk zaman yang baru. Martyn Lloyd-Jones di dalam khotbah yang membahas Markus 9 menyimpulkan "the evangelism and church-growth methods of the past couple of centuries, while perfectly good for their times (he was careful to say that), would no longer work." ${ }^{5}$ Ini menunjukkan pentingnya memperhatikan konteks zaman di dalam memperjuangkan iman Kristen tanpa melayani keinginan zaman tetapi mempengaruhi dan menaklukkan zaman di dalam kebenaran Firman. Konteks, adalah sebuah titik kontak merangkul mereka di dalam kasih Tuhan untuk melihat iman Kristen menjadi satu-satunya kebenaran yang sanggup menjawab tantangan dan memberikan kepuasan yang sejati dalam setiap zaman, maka kontekstualisasi menjadi suatu hal yang penting untuk mengerti dan menjawab zaman. Kontekstualisasi yang salah menghasilkan kompromi sehingga dibutuhkan perhatian yang jeli untuk menghadirkan kontekstualisasi yang sesuai dengan ajaran kekristenan. Kontekstualisasi yang tepat akan membawa zaman kepada kebenaran Injil dan memimpin kepada pengenalan Kristus yang benar. Inilah yang dikerjakan Piper dengan

5 D. Martyn Lloyd-Jones, Revival (Wheaton: Crossway, 1987), 9, 13-15, dikutip dalam John Piper and Justin Taylor, The Supremacy of Christ in a Postmodern World (Wheaton: Crossway, 2007), 105. 
hedonisme Kristen. Ia bukan menghadirkan hedonisme Kristen sebagai kompromi terhadap zaman, tetapi ia menghadirkannya sebagai kontekstualisasi untuk memenangkan zaman bagi Kristus.

Hedonisme Kristen lahir di tengah-tengah arus postmodernisme, arus reaksi terhadap modernisme. Reaksi perlawanan terhadap kungkungan modernisme yang meninggikan rasionalitas. Postmodernisme awalnya menjadi sebuah gerakan yang menolak memutlakkan rasio dan akhirnya berkembang menjadi penolakan terhadap apapun, termasuk "kebenaran sebagai objective truth."6 Kondisi ini menjadi ladang subur bagi perkembangan pluralisme. Manusia terbuka kepada berbagai tawaran alternatif yang ada dan dipandang sebagai sesuatu yang benar. Implikasinya adalah tidak adanya standar bagi kebenaran dan ini berarti pengajaran Kitab Suci sebagai standar kebenaran menghadapi tantangan. Postmodernisme juga mempengaruhi gereja-gereja dalam hal pengajaran kebenaran Firman dimana maknadi dalam Alkitab direlatifkan. Postmodernisme menyatakan bahwa "if we cannot know reality (how things really are), then we cannot know what an author (of a book in the Bible, the Constitution, etc.) really meant."7 Setiap orang boleh memberikan makna sendiri sesuai dengan apa yang mereka anggap sebagai kebenaran. Setiap orang mempunyai makna yang berbeda dan pada puncaknya menyebabkan makna dan kebenaran yang dimaksudkan oleh penulis - Original Meaning - ditiadakan.

6 Ernest Gellner, Postmodernism, Reason and Religion (London: Routledge, 1992), 35.

7 R Scott Smith, Truth and the New Kind of Christian, 19. 
Makna, bagi postmodernisme, dibentuk di dalam komunitas dan setiap komunitas itu mempunyai "bahasanya" membentuk dunia mereka. ${ }^{8}$ Hal ini menyebabkan munculnya banyak gereja, khususnya dimulai di Amerika, banyak gereja tetap melakukan semua kegiatan rutin gereja; tidak ada yang terlewatkan dengan segala perayaannya yang penuh semarak namun Michael Horton mengatakan hanya satu yang tidak ada: "Yesus Kristus." ${ }^{\prime 9}$ Kekristenan terlihat bertumbuh besar tetapi kehilangan kebenaran pokok yang menjadi pusat iman yaitu Allah sendiri. Semua orang, tidak terkecuali orang-orang Kristen mencari kesenangannya dan jalannya sendiri yang dianggap benar untuk menemukan kesenangan itu. Tidak heran teologi kemakmuran bertumbuh subur; orang-orang Kristen terpengaruh ilah zaman bahkan sampai merasuki pemimpin-pemimpin di dalam gereja. Berita yang diajarkan tidak lagi setia kepada kebenaran Kitab Suci; tetapi lebih kepada self-centered teaching untuk mencari kesuksesan dan kesenangan, pusatnya kepada diri sendiri. Horton menggambarkannya dengan kalimat: "Aside from the packaging, there is nothing that cannot be found in most churches today [in America] that could not be satisfied by any number of secular programs and self-help groups." 10

Yohanes Pembaptis mengatakan bahwa "Kristus harus makin besar dan ia harus makin kecil,"11 maka di zaman ini terjadi kebalikannya dimana manusia makin meninggikan dirinya untuk mencari kepuasannya sendiri di

$8 \quad$ Ibid.

9 Michael Scott Horton, Christless Christianity: The Alternative Gospel of the American Church (Grand Rapids: Baker, 2008), 9.

10 Ibid., 16-17.

11 Yoh. 3:30. 
luar Tuhan - "self-seeking pleasure"12 menjadi sebuah tantangan zaman. Manusia makin ditarik menjauh dari Sang Kebenaran sebab manusia menggantikan kebenaran mutlak dengan kebenaran relatif menurut pandangan sendiri di dalam komunitas masing-masing. Mereka juga makin sulit diajar karena pengaruh penolakan terhadap otoritas yang mutlak telah mempengaruhi pemikirannya. Gereja masih meneruskan berita anugerah, namun kegagalan penanaman pentingnya teologi yang meninggikan Kristus akan membawa generasi selanjutnya makin terhanyut di dalam arus dunia ini. Hedonisme Kristen hadir untuk meraih kembali umat Tuhan, khususnya generasi muda dan orang-orang Kristen yang sudah lama meninggalkan gereja karena telah terpikat oleh filosofi dunia. Piper menjalankan panggilan yang diberikan Tuhan kepadanya memberitakan pengejaran sukacita di dalam Kristus kepada kalangan kekristenan dan membawa pengenalan Allah kepada banyak orang sehingga iman di dalam Kristus makin diteguhkan di tengah zaman yang melawan kebenaran ini. Bersamaan dengan hal itu, muncul tokoh-tokoh Kristen yang tidak setuju dengan pandangan hedonisme Kristen yang menurut mereka mengandung bahaya tersembunyi dari filosofi hedonisme yang berpusat pada diri..$^{13}$

\section{Pendekatan Kontekstualisasi Lesslie Newbigin}

Untuk melihat dan memahami hedonisme Kristen sebagai sebuah kontekstualisasi, penulis memaparkannya melalui pendekatan yang

12 Patrick Nullens and Ronald T. Michener, The Matrix of Christian Ethics: Integrating Philosophy and Moral Theology in a Postmodern Context (Colorado Springs: Paternoster, 2010), 71.

13 J. Philip Wogaman, Christian Ethics (London: SPCK, 1994), 21. 
dilakukan oleh Lesslie Newbigin di dalam pelayanan misi yang dikerjakannya. Penulis melihatnya sebagai kontekstualisasi dengan pandangan Newbigin. Berkaitan dengan kontekstualisasi, Newbigin menyatakan bahwa komunikasi memainkan peranan penting supaya kebenaran yang disampaikan dapat dipahami dengan tepat, sehingga berita itu dapat diterima dengan baik di hati pendengar. ${ }^{14}$ Bahasa dan budaya menjadi suatu hal yang harus dipelajari dengan seksama sebagai sarana komunikasi di dalam memberitakan kebenaran. Worldview suatu konteks akan memberikan gambaran penyampaian kebenaran yang sesuai dengan keadaannya dimana relevansi suatu berita dapat dipenuhi. Newbigin melihat bahwa setiap penafsiran Injil diwujudkan dalam kebudayaan tertentu.

The Bible is a book which is very obviously in a spesific cultural setting. Its language. Its language is Hebrew and Greek, not Chinese or Sanskrit. All the events it records, all teachings it embodied, are shaped by spesific human cultures. ${ }^{15}$

Hal ini menunjukkan signifikansi pemahaman suatu konteks di dalam pelaksanaan mandat, tugas misi, dan pengajaran Firman sehingga kebenaran dapat dimengerti secara benar dan menjadi jawaban yang relevan.

Di dalam kontekstualisasi, berita Kitab Suci menjadi dasar utama yang memberikan pengaruh dan memegang kendali. Newbigin tampak memposisikan Injil yang melawan kebudayaan seperti di dalam kritikan berkaitan dengan gerakan the gospel and our culture di Britain. Pandangannya

14 Lesslie Newbigin, The Gospel in a Pluralist Society (Grand Rapid: Eerdmans, 1989), 141.

15 Ibid., 144-45. 
digambarkan sebagai gospel against our culture oleh Elaine Graham dan Heather Walton. ${ }^{16}$ Demikian juga Stephen Bevans ${ }^{17}$ mengkategorikan model kontekstualisasi Newbigin sebagai tambahan model yang ia sebut sebagai the counter-cultural model. ${ }^{18}$ Budaya dilihat sebagai hal yang rusak dan bersifat melawan Injil dan Injil menjadi pengkritik keras budaya. Tinjauan awal Bevans tersebut lebih melihat bahwa pendekatan Newbigin bersifat negatif, tetapi kemudian hari Bevans mengakui sisi positif dari pendekatan Newbigin bahwa pendekatannya ternyata melihat serius tanggung jawab orang percaya terhadap budaya. Pendekatan ini menurutnya banyak ditemukan di antara para teolog yang berhadapan dengan konteks sekuler di barat. ${ }^{19}$ Michael W. Goheen mengungkapkan bahwa meskipun penegasan terhadap kebaikan yang adadi dalam ciptaan dan panggilan kemanusiaan kepada pengembangan budaya tidak ditemukan eksplisit dalam tulisantulisan Newbigin, namun jika diperhatikan secara hati-hati maka secara implisit Newbigin banyak mengakomodasi pengertian tentang kebaikan ciptaan dan peran manusia di dalam pengembangannya, sehingga Newbigin tidak dapat digambarkan sebagai orang yang curiga dan menentang budaya. Menurut Goheen, Bevans benar dengan mengatakan bahwa Newbigin memperhatikan transformasi budaya, mengidentifikasi

16 Michael W. Goheen, Is Lesslie Newbigin's Model of Contextualization Anticultural?, ebook (2002), diakses pada tanggal15 Juli 2015 di dalam laman http://www.newbigin.net/assets/pdf/ 85cfsw.pdf

17 Di dalam bukunya Models of Contextual Theology (Maryknoll: Orbis, 2004), Stephen Bevans membagi kontekstualisasi menjadi beberapa model, yaitu The Anthropological Model, The Translation Model, The Praxis Model, The Synthetic Model dan Transcendental Model.

18 Stephen Bevans, Models of Contextual Theology, edisi kedua (Maryknoll: Orbis, 2002), 143-167.

19 Stephen Bevans, Doing Theology in North America: A Counter-Cultural Model?,Unpublished seminar paper given at Gospel and Our Culture Network conference (Chicago, 1993). 
dan merangkul hal baik di dalam budaya. ${ }^{20}$

\section{Aspek Relevansi dan Kesetiaan di dalam Kontekstualisasi}

Newbigin menyatakan bahwa pandangannya berkaitan dengan Injil dan budaya adalah "The gospel is for and against the culture." 21 Ia mendasari kontekstualisasi ini di dalam konsep Kristologi. ${ }^{22}$ Pertama, Kristus adalah pencipta dan penopang dunia maka gereja harus mengasihi dan bersuka atas seluruh kebaikan di dalam ciptaan. Kedua, Kristus adalah konsumator dari segala sesuatu dan yang memulihkan segala sesuatu, maka gereja, yang berdiri di tengah kebudayaan, akan menjadi sebuah tanda kebenaran akhir (a sign of the true end). Ketiga, Kristus adalah satu-satunya yang telah mati dan bangkit menangggung dosa seluruh dunia, maka gereja akan berdiri tegak melawan kejahatan di setiap tempat. Gereja harus memegang tiga relasi ini dan mengkomunikasikan ketiga hal ini kepada dunia - Inilah kontekstualisasi. Di atas kayu salib terlihat jelas bahwa Kristus di satu sisi diidentifikasikan dengan dunia dan di saat yang sama Kristus dipisahkan dari dunia: "The Cross is one sense an act of total identification with the world. But in another sense it is an act of radical separation. It is both of these at the same time."23 Dengan mengikuti teladan Kristus, gereja melaksanakan

\footnotetext{
20 Ibid.

21 Goheen, Is Lesslie Newbigin's Model of Contextualization Anticultural?

22 Lesslie Newbigin, What is a 'Local Church Truly United'? In Each Place: Towards a Fellowship of Local Churches Truly United, (Geneva: WCC, 1977), 14-29.

23 Lesslie Newbigin, The Good Shepherd: Meditations on Christian Ministry in Today's World, ebook (Oxford: Mowbray, 1977), 98. Diakses pada tanggal15 Juli 2015 di dalam laman http://www.newbigin.net/assets/pdf/77gs.pdf.
} 
panggilannya di dalam pemberitaan kebenaran di dalam setiap konteks yang dihadapi, the church will be for and against its culture.

Meskipun penekanan tampak pada kedua sisi tersebut, Newbigin memulai dengan penegasan "the church is for the world"24 dan Goheen menyatakan bahwa penegasan ini tepat sekali karena Kristus dan gereja diberikan bagi dunia supaya dunia dapat berdiri teguh melawan dosa dan pemberhalaan yang bertentangan dengan kelimpahan hidup dari kebaikan ciptaan. ${ }^{25}$ Dua alasan yang diberikan Newbigin akan penegasan ini. Pertama, budaya memberikan ekspresi kepada kebaikan ciptaan Tuhan. Kedua, gereja hidup dalam solidaritas dengan komunitasnya dalam tanggung jawab budayanya. Dua poin ini disimpulkan dari pendapat Newbigin berkaitan dengan panggilan gereja di barat untuk melaksanakan tanggung jawabnya dalam kehidupan publik:

...the church today cannot without guilt absolve itself from the responsibility, where it sees the possibility, of seeking to shape the public life of nations and the global ordering of industry and commerce in light of the Christian faith. ${ }^{26}$

Goheen menuliskan bahwa penekanan Newbigin pada sisi "against the culture" disebabkan oleh pengalaman pelayanan misinya dimana ia banyak berhadapan dengan budaya-budaya yang melawan Injil, contohnya: agama kuno menentang Injil; pelayanan ekumene dimana ia berjumpa dengan sinkretisme; pelayanan di Britain ia bertemu dengan banyaknya gereja yang

\footnotetext{
24 Lesslie Newbigin, A Word In Season: Perspectives on Christian World Missions (Grand Rapids: Eerdmans, 1994), 53-54.

25 Goheen, Is Lesslie Newbigin's Model of Contextualization Anticultural?

26 Lesslie Newbigin,Foolishness to the Greeks: The Gospel and Western Culture (Grand Rapids: Eerdmans, 1986), 129.
} 
telah berkompromi. ${ }^{27}$ Berhadapan dengan hal-hal itu maka Newbigin menerapkan bahwa budaya harus dibaca dari terang Injil, bukan sebaliknya. Jawaban yang tepat dalam situasi tersebut adalah apa yang disebut Bevans counter-cultural model.28 Faktor penting lain yang membentuk pandangan Newbigin adalah pelayanan misinya di India. Newbigin melakukan street preaching. ${ }^{29}$ Di sini cross-cultural communication menjadi penerapannya. Seorang penginjil harus merelasikan dirinya dengan budaya di dalam dua aspek dimana resiko yang dihadapi adalah masalah hidup dan mati. Di satu sisi harus ada solidaritas; penginjil harus menggunakan bahasa yang dimengerti pendengar - the gospel must be a "at home" in the culture. Di sisi lain harus ada konflik karena berita yang disampaikan harus setia kepada kebenaran Firman yang bertentangan total dengan keyakinan pendengar. ${ }^{30}$

Permasalahan di atas menghadirkan tantangan yang tidak terhindari dalam penginjilan yaitu ketidakrelevanan dan sinkritisme. Jika pemberitaan tidak berelasi dengan budaya maka hal itu menjadi tidak relevan, tetapi jika pemberitaannya berelasi dan bercampur dengan budaya maka hal itu menjadi sinkritisme. Relevansi dan kesetiaan menjadi dua hal yang harus berjalan bersama. Newbigin memaparkan bahwa Yohanes memberikan wawasan yang dalam berikut:

John freely uses the language and thought forms of classical religion and culture that form the world of his hearers-light and darkness, body and soul, heaven and earth, flesh and spirit, and more. Yet John uses this language and thought-forms in such a

27 Goheen, Is Lesslie Newbigin's Model of Contextualization Anticultural?

28 Stephen Bevans, Models of Contextual Theology, 143-167.

29 Goheen, Is Lesslie Newbigin's Model of Contextualization Anticultural?

30 Ibid. 
way as to confront them with a fundamental question and indeed a contradiction. John begins with the announcement "In the beginning was the logos." As he continues it becomes apparent that logos is not the impersonal law of rationality that permeates the universe giving it order but rather the man Jesus Christ. The logos became sarx. John begins by identifying with the classical longing for the source of order expressed in the term logos, but subverts, challenges, and contradicts the idolatrous understanding that had developed in the classical world. ${ }^{31}$

Di dalam kutipan di atas dapat disimpulkan bahwa Yohanes melakukan kedua aspek penting dalam kontekstualisasi, beritanya relevan dan setia.

Model kontekstualisasi Newbigin bukanlah model yang anti dengan budaya. Newbigin mempertahankan kedua aspek penting dalam kontekstualisasi: relevansi dan kesetiaan. Kontekstualisasi di dalam crosscultural communication berarti memperhatikan pentingnya pemahaman situasi, world view, budaya sehingga menjadikan pemberitaan kebenaran tepat pada sasaran dan menghasilkan strategi pemberitaan yang menarik zaman dengan berita yang setia kepada Kitab Suci tanpa kompromi. Kontekstualisasi berarti menyatakan kebenaran dengan keunggulannya, kekuasaannya yang menerobos dengan suatu "gaya hidup" - strategi mengkomunikasikan kebenaran dengan kesetiaan kepada Kitab Suci mentransformasi setiap pemikiran dunia, menaklukkan manusia percaya kepada Kristus sebagai Tuhan di dalam hidupnya. "Contextualization is the question about how the gospel "comes alive" in particular context."32 Comes alive menyatakan bahwa Injil, kebenaran yang memegang kendali dan mengarahkan hidup di dalam setiap konteks sehingga kebenaran Firman

31 Lesslie, Newbigin, The Light Has Come: An Exposition of the Fourth Gospel (Grand Rapids: Eerdmans, 1982), 1-3.

32 Ibid., 152. 
tidak dihanyutkan arus dunia tetapi memakai arus itu untuk mengarahkan dunia kepada kebenaran sejati dimana manusia menemukan tujuan hidupnya.

Kontekstualisasi dapat dilihat juga di dalam pendekatan yang dilakukan oleh Rasul Paulus, ketika ia mengatakan:

Demikianlah bagi orang Yahudi aku menjadi seperti orang Yahudi, supaya aku memenangkan orang-orang Yahudi. Bagi orang-orang yang hidup di bawah hukum Taurat aku menjadi seperti orang yang hidup di bawah hukum Taurat, sekalipun aku sendiri tidak hidup di bawah hukum Taurat, supaya aku dapat memenangkan mereka yang hidup di bawah hukum Taurat. ${ }^{33}$

Juga ketika Paulus memberitakan Kristus di Atena:

Hai orang-orang Atena, aku lihat, bahwa dalam segala hal kamu sangat beribadah kepada dewa-dewa. Sebab ketika aku berjalan-jalan di kotamu dan melihat-lihat barang-barang pujaanmu, aku menjumpai juga sebuah mezbah dengan tulisan: Kepada Allah yang tidak dikenal. Apa yang kamu sembah tanpa mengenalnya, itulah yang kuberitakan kepada kamu. ${ }^{34}$

Paulus menempatkan diri untuk mengerti dan memahami orangorang di dalam konteks hidup mereka masing-masing supaya ia dapat menyampaikan berita kebenaran yang dipahami oleh mereka yang dilayaninya. Segala upaya "menjadi seperti" yang Paulus lakukan, juga ungkapan "kepada Allah yang tidak dikenal" yang Paulus katakan adalah suatu bentuk relevansi konteks yang dikerjakannya bukan untuk alasan penerimaan pemberitaan dengan mengorbankan iman, tetapi memiliki tujuan yang memenuhi aspek kesetiaan terhadap Firman, yaitu untuk

331 Kor. 9:20.

34 Kis. 17:22-23. 
memenangkan mereka bagi Kristus. Terlihat jelas bahwa Paulus memakai situasi, wawasan dan gaya hidup baik orang-orang Yahudi maupun orangorang Atena menjadi sebuah sarana dan strategi untuk menyatakan Injil, ia tidak berkompromi sedikitpun sampai akhirnya ia memberitakan tentang Kristus, Tuhan atas langit dan bumi yang melampaui dewa-dewa buatan manusia. Terlebih itu, kontekstualisasi telah dinyatakan oleh Kristus sendiri melalui inkarnasiNya ke dunia untuk menggenapkan karya penebusan. Kristus mengambil rupa manusia, Ia datang kepada dunia yang berdosa dan tidak berkompromi dalam segala kondisi; Ia mengajarkan kepada dunia tentang kerajaan Allah dan bahkan Ia taat sampai mati di atas kayu salib untuk menebus dan memulihkan kembali umatNya di dalam kebenaranNya bagi kemuliaanNya. Demikianlah kontekstualisasi menjadi suatu hal yang penting di dalam mengerti, menghadapi dan memberi jawaban terhadap tantangan zaman.

\section{Hedonisme Kristen sebagai Kontekstualisasi di dalam Iman Kristen}

Zaman ini Piper menghadirkan hedonisme Kristen sebagai strategi yang mengubah "gaya hidup" sebagai bentuk kontekstualisasi di dalam kekristenan, khususnya di tengah-tengah situasi dunia yang mencari kesenangan dengan berpusat pada diri - Self seeking pleasure. Pandangan Piper yang menjadikan kesenangan sebagai puncak kebaikan, merupakan suatu upaya merangkul zaman, Piper menambahkan istilah Kristen untuk membedakan istilah itu dengan konsep dunia dimana ia meletakkan pengejaran kesenangan di dalam Kristus menjadi pengejaran final untuk 
menjawab kebutuhan zaman. Ini merupakan "aspek relevansi" di dalam pemberitaan kebenaran yang menjadi sebuah titik kontak untuk masuk dan pada saat bersamaan menunjukkan kepada orang-orang bahwa pengejaran yang memberikan kepuasan sejati bukan pengejaran kesenangan yang berpusat pada diri tetapi pengejaran sukacita yang berpusat kepada Allah. Pengejaran sukacita itu hanya mungkin dilakukan di dalam Kristus dan melalui hedonisme Kristen. Piper meninggikan supremasi Kristus sebagai teladan dan sumber sukacita yang berlimpah bagi orang percaya. ${ }^{35}$

"Aspek kesetiaan" akan dibahas dengan memberikan analisa terhadap beberapa perdebatan yang mengkritik hedonisme Kristen. Analisa dikerjakan untuk menunjukkan bahwa meskipun Piper memakai istilah hedonisme Kristen tetapi konsep pengajaran iman yang terkandung di dalamnya setia kepada kebenaran Firman, sekaligus menunjukkan bahwa Piper tidak berkompromi, melainkan kontekstualisasi dalam pengajaran yang ditawarkannya sebagai sebuah gaya hidup di dalam iman Kristen. Berikut dipaparkan beberapa topik perdebatan terhadap hedonisme Kristen; di antaranya pleasure of piety dari Richard Mouw, pendekatan sematik dan teologi dari William Dyrness, pandangan anthropologi dan pneumatologi dari Paul L. Metzger.

\section{Pleasure of Piety}

Terhadap Piper, Mouw mengatakan bahwa konsep hedonisme Kristen tidak berbeda dengan hedonisme Jeremy Bentham yang menyatakan bahwa

35 John Piper, Desiring God: Meditations of a Christian Hedonist, 10th anniversary expanded ed. (Sisters: Multnomah, 1996), 67. 
salah satu kelas penting yang manusia kejar di dalam pleasure adalah

pleasure of piety which accompany the belief of man's being in the acquisition or in possession of the good-will or favour of the Supreme Being: as a fruit of it, of his being in a way of enjoying pleasures to be received by God's special appointment, either in this life, or in a life to come. ${ }^{36}$

Dan hal utama yang berkaitan dengan perspektif hedonistik dalam konsep Bentham tersebut adalah suatu pandangan yang jelas berfokus pada pengejaran keinginan diri, tidak terkecuali pengejaran akan pleasure of piety juga termasuk di dalamnya. ${ }^{37}$ Untuk memperkuat gagasan ketidaksetujuannya ini Mouw juga memakai pandangan John Stuart Mill di dalam versi hedonisme modern yang disebut Utilitarianisme. Mill mengatakan demikian:

We not uncommonly hear the doctrine of utility inveighed against as a godless doctrine. If it be necessary to say anything at all against so mere assumption, we may say that the question depends upon what idea we have formed of the moral character of the Deity. If it be a true belief that God desires, above all things, the happiness of his creatures, and that this was his purpose in their creation, utility is not only not a godless doctrine, but more profoundly religious than any other. If it be meant that utilitarianism does not recognize the revealed will of God as the supreme law of morals, I answer, that a utilitarian who believes in the perfect goodness and wisdom of God, necessarily believes that whatever God has thought fit to reveal on the subject of morals, must fulfill the requirement of utility in a supreme degree. ${ }^{38}$

Di sini menurut Mouw konsep hedonisme Kristen Piper tidak jauh berbeda dengan utilitarianisme Mill, bahkan Piper dianggap meneruskan konsep

\footnotetext{
36 Jeremy Bentham, An Introduction to the Principles of Morals and Legislation (London: W. Pickering, 1823), 1:53.

37 Jeremy Bentham, An Introduction to the Principles of Moral and Legislation, 1:59.

38 John Stuart Mill, Utilitarianism, Liberty, and Representative Government, dengan prakata oleh A.D. Lindsay, Everyman's Library (New York: E. P. Dutton \& Co., 1951), 26.
} 
yang dipandang Mouw sebagai mixed hedonism. ${ }^{39}$ Mungkin saja Piper lebih baik tetapi secara prinsip dianggap sama; dimana kaitan antara Mill dengan Piper terlihat pada penekanan Piper dalam penyembahan yang sangat intens kepada Tuhan dan keseriusan dimana Piper memperlakukan penyataan Tuhan secara langsung. Dengan demikian menurut Mouw dibalik seluruh pencarian pleasure of piety terkandung pengejaran kesenangan diri sendiri yang hanya menjadikan Tuhan sebagai alat pemuas kesenangannya dan ini menunjukkan suatu pemikiran yang mengarah kepada suatu ekspresi perspektif yang hedonistik:

His hedonism certainly aims at more than the accumulation of immediate physical pleasure. But this does not distingush his view from most others who have attempted to give careful expression to a hedonistic perspective. ${ }^{40}$

Menurut Piper, Mouw salah paham terhadap hedonisme Kristen. Mouw menganggap bahwa hedonisme Kristen adalah teori pembenaran moral bagaimana seseorang menentukan apa yang baik di dalam tindakannya, seperti apa yang dilakukan di dalam philosophical hedonism, yang salah satu arti tradisional dari "hedonism" menyatakan bahwa pleasure adalah kriteria tunggal bagi pembenaran moral, tetapi itu bukanlah argumen dari Desiring God ataupun bagian dari hedonisme Kristen. ${ }^{41}$ Piper menegaskan bahwa hedonisme Kristen tidak mengatakan suatu tindakan itu

\footnotetext{
39 Richard J. Mouw, The God Who Commands, 33.

40 Ibid., 32.

41 John Piper, A Response to Richard Mouw's Treatment of Christian Hedonism in "The God Who Commands," diakses pada tanggal11 April 2015 di dalam laman http://www.desiringgod.org/ articles/a-response-to-richard-mouws-treatment-of-christian-hedonism-in-the-god-whocommands.
} 
benar karena tindakan itu mendatangkan pleasure. Tetapi sebaliknya, pengalaman di dalam pleasure tidak berarti cukup menentukan suatu pembenaran moral. Sorotan dari Desiring God bukan untuk memberikan keputusan tindakan apa yang dibenarkan secara moral. Sorotan dari hedonisme Kristen adalah untuk mempertimbangkan dengan implikasi radikal bahwa salah satu hal yang Tuhan perintahkan adalah sukacita: Joy in loving God (Maz. 37:4) dan joy in loving people (Rom. 12:8). Piper menyatakan bahwa tujuan hedonisme Kristen bukanlah menentukan apa yang baik dengan menggunakan sukacita sebagai kriteria moral, tetapi mengakui fakta yang menakjubkan dan tidak terhindarkan bahwa beberapa dimensi dari sukacita adalah sebuah kewajiban moral di dalam semua penyembahan yang benar dan tindakan-tindakan kebajikan. ${ }^{42}$

Piper menyatakan bahwa hedonisme Kristen bukanlah suatu hasil pendekatan secara hedonistik terhadap Kitab Suci, tetapi hedonisme Kristen merupakan hasil penyelidikan di dalam Kitab Suci tentang perintah ilahi untuk menjadi seorang pengejar kesenangan:

that is, to forsake the two-bit, low-yield, short-term, never-satisfying, persondestroying, God-belittling pleasures of the world, and to sell everything "out of joy" (Matt. 13:44) in order to have the kingdom and thus "enter into joy of [our] Master" (Matt. 25:21, 23).43

Di sini Piper menunjukkan bahwa hedonisme Kristen bukan sebuah alternatif terhadap sistem yang Mouw pikirkan, tetapi hedonisme Kristen adalah hasil dari penekanan Mouw terhadap perintah ilahi dengan penuh

\footnotetext{
42 Ibid.

43 Piper, A Response to Richard Mouw's Treatment of Christian Hedonism.
} 
komitmen, sehingga hedonisme Kristen bukan hadir karena alasan secara filosofi dunia tetapi karena ketaatan kepada perintah Tuhan. ${ }^{44}$

Berkaitan dengan kesukaan di dalam ketaatan akan perintah Tuhan; John Calvin, khususnya pada pembahasan peranan hukum yang ketiga (Calvin's third use of the law), yang merupakan bagian yang diperuntukkan bagi orang-orang percaya dimana ia mengingatkan bahwa hubungan antara law dengan delight itu tidak dapat dipisahkan. Law itu bukan hanya sebagai sesuatu aturan yang mengikat saja tetapi lebih daripada itu, melalui dan di dalam law ada fungsi radikal (digambarkan sebagai cambuk dan sengat) yang membawa mereka yang taat kepada law itu memperoleh delight. Di dalam anugerah Allah, law ini menemukan fungsi dan kegunaannya secara sempurna di dalam diri Kristus. Demikian Calvin menuliskannya di dalam The Institute of Christian Religion:

The Lord instructs by their reading of it those whom he inwardly instils with a readiness to obey. He lays hold not only of the precepts, but the accompanying promise of grace, which alone sweetens what is bitter.... David especially shows that in the law he apprehended the Mediator, without whom there is no delight or sweetness. ${ }^{45}$

Dengan kata lain Piper menyatakan bahwa sebagai seorang hedonis Kristen maka tidak ada alasan lain daripada mengejar dan memperoleh kesenangan di dalam Dia.

Then I (Piper) was converted to Christian Hedonism. In a matter of weeks I came to see that it is unbiblical and arrogant to try to worship God for any other reason than the pleasure to be had in him. (Don't miss those last two words: IN HIM. Not gifts,

\footnotetext{
44 Ibid.

45 John Calvin, The Institutes of the Christian Religion, terj. Henry Beveridge (Grand Rapids: Christian Classical Ethereal Library, 2002), II.vii.12.
} 
but Him. Not ourselves, but him). ${ }^{46}$

Dengan demikian dapat dijelaskan bahwa pandangan Mouw yang melihat hedonisme Kristen sebagai kesamaan di dalam ajaran filosofi yang disebut pleasure of piety merupakan sebuah perhatian yang baik untuk berpegang ketat kepada hukum Tuhan, namun apa yang diungkapkan Mouw lebih menyentuh kepada fenomena istilah dari hedonisme Kristen. Piper menyanggah pendapat Mouw dengan ungkapan "salah paham," sebab ajaran filosofi menekankan pada apa yang dikejar dan diinginkan manusia sebagai sebuah tujuan yang paling ultimat, sedangkan hedonisme Kristen meletakkan pengejaran pleasure bukan semata-mata pada pleasure itu sendiri tetapi landasannya, jika boleh meminjam istilah Mouw adalah di dalam "divine commands" yang Piper sebut dengan suatu ungkapan yang ia sorot dari perspektif Mouw, yaitu "the God who commands Joy." Fokus dari hedonisme Kristen adalah God's command, dan Piper menegaskan bahwa di dalam hedonisme Kristen, landasan happiness seorang hedonis Kristen adalah the happiness of God. ${ }^{47}$

Pemaparan di atas menunjukkan bahwa Mouw lebih melihat dengan pendekatan penilaian yang didasarkan pelaksanaan suatu kewajiban norma atau hukum (deontological approach) dimana ia meletakkan fokus perhatiannya kepada perintah Allah sehingga semua pengajaran yang mengandung aspek pertentangan dengan hukum Allah dalam bentuk apapun harus ditolak. Sedangkan Piper lebih melihat dari sisi kebaikan

\footnotetext{
46 John Piper, Desiring God: Meditations of a Christian Hedonist, [10th anniversary expanded ed. (Sisters: Multnomah,1996), 16.

47 Piper, Desiring God, 35.
} 
tujuan yang tidak terhindarkan di dalam penyembahan iman Kristen (teleological approach) dimana ia melihat bahwa sukacita sebagai perintah Allah yang harus dikejar oleh setiap orang percaya. Hal penting yang harus dicatat adalah Piper tidak menghalalkan segala cara di dalam pengejarannya. Hedonisme Kristen meletakkan pengejarannya bukan kepada kesenangan itu sendiri tetapi kepada kesenangan di dalam diri Allah yang merupakan sumber kesenangan umatNya. Dengan demikian apa yang disebut dengan pleasure of piety tidak mewakili dan melukiskan secara total pandangan atau ajaran hedonisme Kristen. Berkaitan dengan hal ini, dapat disimpulkan bahwa lebih tepat ungkapan yang dipakai untuk melukiskan hedonisme Kristen bukanlah pleasure of piety tetapi pleasure in piety. Kesalehan hidup di dalam ketaatan kepada perintah Allah di dalam Kristus menjadi fokus dan dasar utama dimana pengejaran kepada kesenangan yang benar itu menjadi tuntutan yang tidak bisa dihindari karena ketaatan tersebut dan di dalam ketaatan itu pleasure menjadi suatu kenikmatan sejati yang hanya bisa diperoleh di dalam Kristus.

\section{Pendekatan Semantik dan Teologi}

Dyrness menganggap Piper melakukan pendekatan semantik yaitu penyederhanaan terhadap penggunaan kata-kata seperti pleasure, affections dan joy, juga ketika mengutip kata-kata yang berasal dari kitab suci seperti benefit, delight dan joy. Dyrness menunjukkan misalkan kata "enjoy" pada katekismus Westminster di dalam penggunaan bahasa Inggris kuno tidak harus dipakai untuk menikmati kesenangan tetapi bisa dipakai untuk menyatakan suatu keuntungan yang di dapat di dalam menghadapi 
kesulitan: "She enjoyed ill health," sedangkan kata "enjoy" sekarang sudah lebih kepada sesuatu yang keuntungan yang berorientasi subyektif kesenangan subyektif.

Di dalam pendahuluan Desiring God, Piper mengatakan bahwa ia menemukan dirinya sebelum menjadi seorang hedonis Kristen, ia merasakan bahwa penyembahan di dalam hidupnya tampak seperti sebuah kewajiban, sedangkan ia menemukan di dalam dirinya suatu kerinduan yang besar untuk bahagia, suatu keinginan "to seek pleasure." 48 Di dalam pergumulan itu ia sadar bahwa: "it is unbiblical and arrogant to try to worship God for any other reason than the pleasure to be had in him,"49 maka penyembahan sejati bukan sekedar memantulkan cahaya kemuliaan Allah tetapi lebih tepat sebagai sesuatu hal yang dilakukan dengan "senang hati." 50 Jika seseorang mengira bahwa hasrat "enjoyment" adalah suatu hal buruk maka Piper mengatakan hal ini sudah terjebak ke dalam pemikiran Immanuel Kant dan kaum Stoics. ${ }^{51}$ Oleh sebab itu pengejaran kesenangan di dalam Tuhan bukan sesuatu yang buruk dan bersifat subyektif, tetapi merupakan "personal relationship with God." Pengejaran kesenangan acap kali ditujukan kepada hal-hal berkaitan dengan makan, minum dan seksual. Melampaui hal itu, Piper mengatakan Tuhan telah menyediakan kepada kita "infinite joy....we are too easily pleased." 52

\footnotetext{
48 Piper, Desiring God, 16.

49 Ibid.

50 Ibid., 79.

51 Ibid., 17.

52 Ibid.
} 
Selain itu Piper juga menjelaskan enjoyment di dalam suffering. Kata sengsara di dalam dunia berdosa telah mengalami pengenceran makna yaitu saat dimana kesenangan tidak tercapai, sengsara dipakai sebagai salah satu cara "menyuap"- melepaskan diri dari rasa bersalah dan dosa demi terhindar dari penghakiman atau mencapai kesempurnaan. Sengsara di dalam kekristenan merupakan suatu pengorbanan yang dilakukan bersama dan bagi Kristus di dalam perjalanan iman mengikut Dia. Hal ini berarti bahwa sengsara menjadi ujian dan bukti kesetiaan umatNya terhadap kebaikan dan kuasaNya, sekaligus mengungkapkan betapa bernilainya Kristus sebagai kepuasan yang mencukupi dan melebihi segala sesuatu. ${ }^{53}$

Jika dikatakan Piper melakukan penyederhanaan kata-kata, contohnya untuk kata "enjoy" diatas, Piper justru mengakomodasi dan membedakan makna keduanya dengan menjelaskan enjoyment di dalam pengejaran kesenangan di dalam seluruh aspek hidup seorang Kristen baik dalam suka dan duka dan membedakan keduanya dimana ia menjelaskan perbedaan antara kesenangan dunia dengan kesenangan Kristen. Kesenangan dunia hanya berkaitan dengan keuntungan subyektif untuk pencapaian maksimal sense of experience of pleasure sebagai the highest good ${ }^{4}$ sebagai akhir dari pencapaian itu sendiri sedangkan kesenangan Kristen adalah sebuah pengenalan akan Tuhan, baik di dalam pemikiran maupun segala aspek hidup sebagai suatu ketaatan kepada perintahNya yang pada akhirnya memimpin orang percaya kepada Tuhan. Piper menyatakannya dengan kalimat: "God is glorified in his people by the way we experienced him, not

\footnotetext{
53 Ibid., 216

54 Carl F. H. Henry, Christian Personal Ethics, 24.
} 
merely by the way we think about him." 55

Demikian juga Piper membedakan sengsara dunia dan sengsara Kristen. Sama seperti kesenangan yang mempunyai akhir pada dirinya sendiri demikian juga konsep sengsara dunia. Ini sesuatu yang tragis karena kesengsaraan yang dunia lakukan dengan segenap usaha diri demi sesuatu kebahagiaan yang belum jelas di masa yang akan datang. Konsep ini dapat dilihat di dalam jawaban seorang kepala biara di dalam tradisi Cistercian $^{56}$ di dalam hidup keheningan dan kesendirian pada sebuah wawancara televisi di Italia atas pertanyaan "What if you were to realize at the end of your life that atheism is true, that there is no God?"57 Kepala biara itu menjawab: "Holiness, silence dan sacrifice are beautiful in themselves, even without promise of reward. I still will have used my life well." 58 Kekristenan melihat dengan perspektif yang berbeda total, sebab kebahagiaan tertinggi dalam kekristenan telah diterima dan dinikmati di dalam Kristus yang telah bangkit sehingga kesengsaraan yang dialami tidak akan merampas sukacita itu; bertekun di dalam kesengsaraan karena Kristus menyatakan kesetiaan sejati semakin memancarkan kemuliaan Tuhan yang adalah obyek dari kesenangan umatNya. ${ }^{59}$ Tanpa kebangkitan Kristus maka semua sengsara yang dialami

\footnotetext{
55 John Piper, When i Don't Desire God: How to Fight for Joy (Wheaton: Crossway, 2004), 30.

56 Cistercian adalah salah satu ordo di dalam Katolik Roma yang didirikan oleh sekelompok kecil biarawan tahun 1098 di Citeaux, Burgundy, Prancis.Awalnya, ordo ini tidak begitu berkembang hingga masuknya seorang biarawan muda yang bernama Bernardus yang dikenal sebagai Santo Bernardus dari Clairvaux. Sejak itulah ordo ini berkembang pesat ke seluruh Eropa, lihat dalam Michael Collins dan Matthew Arlen Price, The Story of Christianity (Yogyakarta: Kanisius, 2006), 107.

57 Piper, Desiring God, 213.

58 Ibid.

59 Piper, A Response to Richard Mouw's Treatment of Christian Hedonism.
} 
menjadi sesuatu hal yang sia-sia. Paulus di dalam Roma 12:12 menyatakan bahwa karena kebangkitan Kristus maka di dalam sengsara itu ada pengharapan - "rejoicing in hope." Maka Piper berpendapat tentang sukacita di dalam sengsara dengan berkata:

Yes, there was joy and sense of great significance in his [Paul] suffering. But the joy was there only because of the joyful hope beyond suffering. This is the point of Romans 5:3-4: "we exult in our afflictions, knowing that afflictions produces endurance, and endurance produces proven genuineness, and genuineness produces hope." So there is a joy in affliction. But the joy comes because of the hope that affliction itself is helping to secure and increase. If there is no hope, Paul is fool to embrace this affliction, and even more foolish to rejoice in it. ${ }^{60}$

Kritik semantic berikutnya berkaitan dengan penggunaan "afeksi" yang diambil dari pandangan Edwards. Dyrness melihat bagi Edwards afeksi itu sesuatu yang menggerakkan kehendak dan meningkatkan kendali kondisi jiwa di dalam keadaan senang maupun sengsara tetapi menurutnya Piper hanya memakai afeksi sebagai motivasi setara dengan emosi positif seperti kesenangan. Piper menyatakan dengan tegas bagaimana afeksi menjadi sesuatu yang penting di dalam penyembahan seorang hedonis Kristen dan kata emosi di dalam penyembahan, bukanlah emosi secara dangkal tetapi ia mengaitkannya dengan kebenaran. Piper mengatakan:

Truth without emotions produces dead orthodoxy and a church full (half-full) of arificial admirers (like people who write generic anniversary cards for a living). On the other hand, emotion without truth produces empty, frenzy and cultivates shallow people who refuse the discipline of rigorous thought. But true worship comes from people who are deeply emotional and who love deep and sound doctrine. Strong affections for God rooted in truth are the bone marrow of biblical worship. ${ }^{61}$

60 Ibid., 215.

61 Piper, Desiring God, 76. 
Kata emosi di dalam konteks afeksi, dijelaskannya sebagai emosi yang berakar di dalam kebenaran dan esensi di dalam penyembahan kepada Tuhan. Kesenangan dalam penyembahan tidak terbatas pada keadaan positif tetapi juga pada kondisi kesengsaraan sehingga afeksi justru menggambarkan kesejatian iman seorang Kristen. Sengsara namun bersukacita di dalam pengharapan tanpa perlu dibuat-buat, secara spontan sehingga di dalam keadaan sengsara sekalipun, penyembahan itu hadir: "Worship is a way of gladly reflecting back to God the radiance of his worth."62 Piper menyatakan bahwa ini hanya bisa terjadi ketika "spontaneous affections arise in the heart." 63 Dalam pengertian yang dijelaskan di atas maka dapat dinyatakan bahwa Piper tidak hanya menggunakan afeksi sebagai emosi positif bagi kesenangan saja. Namun ia menyatakan afeksi yang berakar kepada kebenaran Firman yang merupakan elemen esensial di dalam penyembahan sejati seorang hedonis Kristen.

Dalam Pendekatan Teologi, Dyrness mengkritisi Piper di dalam konsep kedaulatan Allah. Menurutnya, Piper melihat bahwa Allah tidak secara radikal berelasi dengan ciptaanNya, kedaulatanNya memisahkan diriNya dari tatanan ciptaan ini dan membuat Allah dapat menempatkan kebaikan dan kejahatan secara bersamaan - hal itu memuaskanNya dan membuat kesenanganNya tidak tergoyahkan. Bagi Dyrness kesenangan Allah dapat tergoyahkan karena Ia dimotivasi selain kesenanganNya juga relasiNya dengan tatanan dunia yang telah jatuh. Dyrness merujuk pada tradisi di kitab Hosea dan Yeremia dimana Allah sangat sedih melihat

\footnotetext{
62 Ibid., 83.

63 Ibid.
} 
kejahatan yang ada. Relasi ini adalah kasihNya yang penuh belas kasihan.

Piper melihat bahwa kesenangan Allah tidak tergoyahkan karena ia menyatakan bahwa fondasi dari kesenangan Allah itu adalah kedaulatanNya. ${ }^{64}$ Di dalam kedaulatanNya ini Allah melakukan segala sesuatu bagi kemuliaanNya dan di dalam kemuliaanNya Ia menikmati seluruh rencanaNya, sebab tidak ada sesuatu pun rencanaNya yang gagal. ${ }^{65}$ Hal serupa dapat ditemukan juga di dalam pemikiran Edwards dimana Allah di dalam kedaulatanNya bersukacita di dalam diriNya sendiri:

Because [God] infinitely values his own glory, consisting in the knowledge of himself, love to himself . . . joy in himself; he therefore valued the image, communication or participation of these, in the creature. And it is because he values himself, that he delights in the knowledge, and love, and joy of the creature; as being himself the object of this knowledge, love and complacence. ... [Thus] God's respect to the creature's good, and his respect to himself, is not a divided respect; but both are united in one, as the happiness of the creature aimed at, is happiness in union with himself. ${ }^{66}$

Apa yang menjadi pemikiran Dyrness di dalam gambaran kedaulatan Allah di dalam relasi dengan umatNya, sebenarnya dapat ditemukan di dalam pemikiran Piper yang berdasarkan pada pergumulan Edwards akan kedaulatan Allah di dalam hidupnya. Piper menggambarkan kedaulatanNya Allah melihat dengan dua lensa:

When God looks at painful or wicked even through his narrow lens, he sees tragedy or the sin for what it is itself and he is angered and grieved. But when God looks at painful or wicked even through his wide-angle lens, he sees tragedy or sin in relation to everything leading up to it and everything flowing out from it. He sees it in

\footnotetext{
64 Piper, Desiring God, 35.

65 Yes. 46:9-10.

66 Jonathan Edwards, "The Dissertation Concerning the End for Which God Created the World," in The Works of Jonathan Edwards, vol. 8, Ethical Writings, ed. Paul Ramsey (New Haven: Yale University Press, 1989), 532-533 (emphasis added).
} 
relation to all the connections and effects that form a pattern or mosaic stretching into eternity. This mosaic in all its parts - good and evil - brings him delight. ${ }^{67}$

Dengan kata lain Piper melihat kedaulatan Allah di dalam perspektif kekekalan Allah yang penuh kemuliaan, sedangkan pemikiran Dyrness yang melihat bahwa kesenangan Allah dapat tergoyahkan karena ia melihat kedaulatan Allah yang dinyatakan di dalam perspektif realitas yang dinyatakan kepada umatNya di dalam tatanan dunia ciptaan dimana Allah menyatakan relasinya dengan menunjukkan di dalam kekudusanNya ia membenci dan sangat bersedih atas segala kejahatan. Kedua pandangan tentang kedaulatan Allah tersebut merupakan sebuah pandangan indah yang menyatakan bahwa Allah memang berdaulat di dalam segala realitas yang baik dan jahat. Piper mengatakan ketika Edwards memahami perkataan "God is God," maka pandangan yang ia lihat adalah:

an absolutely sovereign God, self-sufficient in himself and all-sufficient for his creatures, infinite in holiness, and therefore perfectly glorious. He does everything that he does - absolutely everything - for the sake of displaying his glory. ${ }^{68}$

Dan Piper mengekspresikannya dengan kalimat "God delight in his own glory." 69

\footnotetext{
67 Piper, Desiring God, 40.

68 John Piper, "A God-Entranced Vision of All Things: Why We Need Jonathan Edwards 300 Years Later," 23.

69 John Piper, Desiring God, 44.
} 


\section{Pandangan Antropologi dan Pneumatologi}

Metzger berpendapat bahwa di dalam theological anthropology of christian hedonism, afeksi memegang peranan kunci. ${ }^{70}$ Di sini Metzger melihat bahwa penuntutan terhadap hasrat akan sukacita menimbulkan pertanyaan antropologi apakah will - kehendakmemuliakan Allah berasal dari hasrat hati, desire atau hasrat yang bergantung pada kehendak? Dan masalah ini diteruskan ke dalam sisi pneumatologi; pertanyaannya adalah apakah Roh Kudus memampukan kehendak, will untuk membakar hasrat atau Roh Kudus yang menimbulkan hasrat, desire? Berkaitan dengan hal ini Metzger melihat bahwa hedonisme Kristen dianggap kurang mementingkan peranan Roh Kudus di dalam memimpin motif. ${ }^{71}$

Konsep will Piper didasarkan pada pemikiran Edwards bahwa will dan desire terletak di dalam bagian fakultas yang sama; disebut Edwards, inclination $^{72}$ dan penting diperhatikan bahwa relasinya tidak bisa dipisahkan dengan fakultas understanding ${ }^{73}$ untuk menghasilkan true worship affections. Relasi yang lebih baik bukan terletak di dalam urutan mana yang lebih dahulu muncul mempengaruhi adanya kehendak dan hasrat, tetapi lebih kepada pengaruh ketergantungan di dalam kedua relasi tersebut. Kehendak tidak menghasilkan hasrat dan hasrat juga tidak menghasilkan kehendak, tetapi hasrat tanpa kehendak hanyalah sebuah harapan kosong, sedangkan

\footnotetext{
70 Metzger, Paul Louis. 2005. "The halfway house of hedonism: potential and problems in John Piper's Desiring God." Crux 41, no. 4: 21-27. ATLA Religion Database with ATLASerials, EBSCOhost (diakses pada 5 Juni, 2015).

71 Ibid.

72 William J. Danaher, The Trinitarian Ethics of Jonathan Edwards, Columbia Series in Reformed Theology (Louisville: Westminster John Knox Press, 2004), 120.

73 Ibid.
} 
kehendak tanpa hasrat akan terjebak ke dalam rutinitas kewajiban belaka. Kehendak dan hasrat tidak dapat dipisahkan kepentingannya karena keduanya harus ada di dalam rangka pengejaran sukacita seorang hedonis Kristen.

Afeksi mempunyai peranan penting di dalam hedonisme Kristen, tetapi bukan karena afeksi itu diletakkan di dalam konteks pemikiran kehendak dan hasrat dalam arti produksi. Jika demikian maka afeksi itu memang benar merupakan sebuah upaya manusia di dalam kehadirannya. Namun afeksi bukan hanya bergantung kepada kedua hal itu karena masih ada aspek understanding yang merupakan satu kesatuan di dalam fakultas jiwa manusia dan pada poin ini pengenalan yang benar di dalam understanding akan sangat mempengaruhi kehendak dan hasrat di dalam kehadiran afeksi-afeksi tersebut. Pengenalan akan Tuhan di dalam kebenaran FirmanNya menjadi satu-satunya jalan dimana sukacita sejati itu akan mengalir keluar di dalam hidup seorang hedonis Kristen dengan segala kepenuhannya; bukan karena harapan kosong dan rutinitas penyembahan, tetapi karena hati yang penuh dengan kehendak di dalam kebenaranNya yang memancarkan hasrat dengan true affections hanya bagi dan demi kemuliaanNya.

Pengenalan akan Firman Tuhan, terutama bukan karena kehendak dan hasrat manusia sendiri. Karena manusia yang berdosa tidak mempunyai kerinduan untuk mengenal Tuhan dan kebenaranNya sebab segala jalan hidupnya hanya mencari worldly pleasure yang berlawanan dengan tujuan ia diciptakan. Pengenalan kebenaran kepada Sang Firman Hidup hanya mungkin diperoleh di dalam anugerah yang menguduskan 
faculties of the soul sehingga memancarkan afeksi-afeksi sejati dan tanpa hal itu, manusia tidak mungkin menemukan kelimpahan sukacita di dalam hidupnya. Dosa telah membuat seluruh aspek hidup manusia tercemar termasuk aspek understanding, maka hanya kebenaran Firman yang sanggup menaklukkan aspek reason. Stephen Tong menjelaskan perkataan kalimat Martin Luther yang mengejutkan: "Rasio itu pelacur."74 Ia menjelaskan bahwa rasio dapat diperalat untuk pembenaran diri terhadap dosa yang dilakukan seseorang di dalam ketidaksetiaan terhadap kebenaran di dalam hidupnya. Jika dibandingkan di dalam pemikiran Edwards, maka dapat dikatakan bahwa rasio yang diperalat tersebut dapat menghasilkan afeksi tetapi itu adalah "worldly affections."75 Oleh karena itu sangat esensial bahwa faculties of the soul yang dikuasai oleh Firman yang akan menghasilkan afeksi-afeksi seorang Kristen seperti yang Edwards sebut dengan "religious affections." Dan implikasinya menghasilkan pengertian "knowing God with our minds and enjoying God with our hearts."76

Hanya melalui pertobatan di dalam konversi yang sejati seorang hedonis Kristen diciptakan, maka hati yang baru; hati yang haus akan kebenaran dan mencari kesenangan di dalam kebenaran itu lahir. Piper dengan jelas mengatakan bahwa ini adalah karya Roh Kudus.

Conversion does indeed include an act of will by which we renounce sin and submit ourselves to the authority of Christ and put our hope and trust in him. We are

\footnotetext{
74 Stephen Tong, Iman, Rasio Dan Kebenaran (Jakarta: Institut Reformed, Stephen Tong Evangelistic Ministries International: 1996), 73.

75 William J. Danaher, The Trinitarian Ethics of Jonathan Edwards, 122.

76 John Piper, "A God-Entranced Vision of All Things: Why We Need Jonathan Edwards 300 Years Later," dalam A God Entranced Vision of All Things: The Legacy of Jonathan Edwards, diedit oleh John Piper dan Justin Taylor (Wheaton: Crossway, 2004), 25.
} 
responsible to do this, and will be condemned if we don't. but just as clearly the Bible teaches that, owing to our hard heart and willful blindness and spiritual insensitivity, we cannot do this. We must first experience the regenerating work of the Holy Spirit. ${ }^{77}$ The Scriptures promised ${ }^{78}$ long ago that God would devote himself to this work in order to create for himself a faithful people. ${ }^{79}$

Selain itu, Piper di dalam hedonisme Kristen sangat mengutamakan Kristus yang adalah cahaya kemuliaan Allah. Seluruh pencarian kepuasan sukacita di dalam Allah hanya bisa mencapai kesempurnaannya di dalam Kristus. Piper mengatakan bahwa:

the ultimate goal of the cross - the ultimate good of the gospel ${ }^{80}$ - is the everlasting enjoyment of God. The glorious work of Christ in bearing our sins and removing God's wrath and providing our righteousness is aimed finally this: "Christ also suffered once for sin, the righteous for the unrighteous, that he might bring us to God (1 Pet. 3:18). Jesus died for us so that we might say with the psalmist, "I will go to the altar of God, to God my exceeding joy" (Ps. 43:4). ${ }^{81}$

\section{Di dalam Kitab Suci, Yesus Kristus berkata:}

Tetapi apabila Ia datang, yaitu Roh Kebenaran, Ia akan memimpin kamu ke dalam seluruh kebenaran; sebab Ia tidak akan berkata-kata dari diri-Nya sendiri, tetapi segala sesuatu yang didengar-Nya itulah yang akan dikatakanNya dan Ia akan memberitakan kepadamu hal-hal yang akan datang. Ia akan memuliakan Aku, sebab Ia akan memberitakan kepadamu apa yang diterimanya dari pada-Ku. Segala sesuatu yang Bapa punya, adalah Aku punya; sebab itu Aku berkata: Ia akan memberitakan kepadamu apa yang

\footnotetext{
77 Piper, Desiring God, 62 (penambahan digarisbawahi).

78 Ul. 30:6, Yer.24:7, Yeh. 11:19-20, Yeh. 36:26-27.

79 Piper, Desiring God, 62.

80 John Piper, God Is the Gospel: Meditations On God's Love as the Gift of Himself (Wheaton: Crossway, 2011), 102.

81 John Piper, "Joy and the Supremacy of Christ in a Postmodern World," dalam The Supremacy of Christ in a Postmodern World, ed. John Piper dan Justin Taylor (Wheaton: Crossway, 2007), 77.
} 
diterimanya dari pada-Ku. ${ }^{82}$

Dengan demikian jelas bahwa setiap pekerjaan yang meninggikan supremasi Kristus di dalam segala hal, dalam hal ini, pursuit of Joy in Christ adalah pekerjaan mutlak Roh Kudus. Oleh karena itu kurang tepat mengatakan bahwa Piper kurang mementingkan peran Roh Kudus di dalam hidup seorang hedonis Kristen yang mana olehNya ia diciptakan untuk mengejar dan menikmati sukacita surgawi yang telah disediakan baginya.

\section{Kesimpulan}

Dari pembahasan di atas menunjukkan relevansi dan kesetiaan Piper kepada kebenaran Firman membuat hedonisme Kristen bukan merupakan suatu bentuk kompromi tetapi sebuah kontekstualisasi di dalam iman Kristen. Dengan demikian dapat disimpulkan bahwa Piper di dalam kontekstualisasi memahami kebutuhan zaman, tidak membawa orang-orang kepada kebenaran yang mereka cari masing-masing sesuai dengan keinginan worldview mereka, namun ia membawa mereka kepada the ultimate Joy yang menjadi satu-satunya objective truth di dalam pengejaran kesenangan hidup mereka.

Berita kebenaran yang disampaikan Piper sesuai dengan pernyataannya tentang tiga hal penting yang harus diperhatikan di dalam menyampaikan kebenaran Firman: "The goal of preaching is the Glory of God, the ground of preaching is the Cross of Christ and the gift of preaching is the power

82 Yoh. 16:13-15. 
of the Holy Spirit;83 sehingga world view self-seeking pleasure menjadi titik kontak sebagai "aspek relevansi" yang merupakan situasi zaman dimana manusia di dalam ketersesatannya telah terpengaruh untuk mencari kesenangan pada dirinya sendiri. Piper masuk di dalam pencarian itu, tetapi ia tidak hanyut di dalam arus tersebut, melainkan ia membawa mereka yang di dalam pencarian itu kepada the ultimate Joy yang berdasarkan kepada pengajaran di dalam Kitab Suci - "aspek kesetiaan."

Disini dapat dilihat bahwa apa yang dikomunikasikan di dalam kontekstualisasi yang ia kerjakan menjadi suatu strategi pelaksanaan mandat mulia Tuhan untuk membawa sebuah generasi dalam suatu zaman kembali kepadaNya. Kontekstualisasi ini dikerjakan Piper di dalam suatu framework, disebutnya hedonisme Kristen yang mengejar kesalehan hidup bagi pertumbuhan iman Kristen dengan mengejar hanya sukacita yang Tuhan perintahkan dan sediakan bagi umatNya. Akhir kata Piper mengingatkan bahwa: "God is most glorified when we are most satisfied in him." 84 Soli Deo Gloria.

83 John Piper, The Supremacy of God in Preaching, rev. ed. (Grand Rapids: Baker, 2004), 23.

84 Piper, Desiring God, 9. 